\title{
Can Sediments Contaminated by Mining be a Source of Mercury in the Coastal Environment Due to Dredging? Evidence from Thermo-Desorption and Chemical Speciation
}

\author{
Stefano Covelli ${ }^{1}\left[\right.$ Elisa Petranich ${ }^{1} \cdot$ Elena Pavoni $^{1,2} \cdot$ Sergio Signore $^{3}$ \\ Received: 6 November 2020 / Accepted: 15 February 2021 / Published online: 2 March 2021 \\ (c) The Author(s) 2021
}

\begin{abstract}
The sediments in the Gulf of Trieste (northern Adriatic Sea, Italy) are contaminated by mercury ( $\mathrm{Hg}$ ) due to historic mining which took place in Idrija (Slovenia). Despite many studies having been done regarding $\mathrm{Hg}$, no information is available on the potential impact of dredging required along the main channel approaching the Port of Monfalcone. Sixteen surface sediment samples were collected along the channel to determine both total $\mathrm{Hg}$ concentration and chemical species using the thermo-desorption (TD) technique. Six samples were also chosen to apply a selective sequential extraction (SSE). The $\mathrm{TD}$ technique showed the maximum $\mathrm{Hg}$ release approximately at 260 and $335^{\circ} \mathrm{C}$, corresponding to metacinnabar $(\beta$ - $\mathrm{HgS})$ and cinnabar $(\alpha-\mathrm{HgS})$, respectively. The SSE demonstrated that $\mathrm{Hg}$ was mainly associated with poorly soluble or insoluble compounds $(98.7 \%)$. A resuspension event over a limited period of time can be considered of negligible impact to the water column due to the scarce $\mathrm{Hg}$ mobility from sediments.
\end{abstract}

Keywords Sediments $\cdot$ Dredging $\cdot$ Mercury $\cdot$ Chemical speciation $\cdot$ Bioavailability

Most ports are usually important sites of industrial and urban activities and are recognised as potential reservoirs for organic and inorganic contaminants which, due to poor environmental management, accumulate in the bottom sediments (e.g. Schintu et al. 2016). Sediments can be a secondary source of contamination due to both desorption of the labile components (Caplat et al. 2015), remobilisation (Kelderman and Osman 2007) and resuspension events (Gibson et al. 2015; García-Ordiales et al. 2020) as a result of changes in the physico-chemical conditions. For instance, dredging to ensure safe navigation can modify the original physico-chemical features of sediments due to their partial resuspension in the water column (Fisher et al. 2015), also

Stefano Covelli covelli@units.it

1 Dipartimento Di Matematica E Geoscienze, Università Degli Studi Di Trieste, Via Weiss 2, 34128 Trieste, Italy

2 Dipartimento Di Scienze Chimiche E Farmaceutiche, Università Degli Studi Di Trieste, Via Giorgieri 1, 34127 Trieste, Italy

3 Autorita' di Sistema Portuale del Mare Adriatico Orientale - Porto di Trieste, via Karl Ludwig von Bruck, 3, 34144 Trieste, Italy having negative effects on the benthic biota (e.g. Moog et al. 2018). The eventual desorption of chemical species from the solid phase can lead to the formation of more mobile, reactive and toxic chemical forms, potentially bioavailable to the aquatic trophic chain (Schneider et al. 2018).

Increasing concern about the contamination of sediments has resulted in European as well as national regulations enforcing severe control and monitoring of contaminated sediment movements. There is also a continuing debate on the possible harm that the physical resuspension of contaminated sediments might cause to the trophic chain and marine activities such as mussel and fish farming (e.g. Bocchetti et al. 2008).

The marine coastal environments of the northern Adriatic Sea (Italy) have been widely investigated in relation to the historical mercury $(\mathrm{Hg})$ contamination associated with the Idrija (NW Slovenia) mining activity which was in operation for 500 years (Covelli et al. 2001). Contamination is due to the fluvial inputs of the Isonzo/Soča River system discharging into the Gulf of Trieste (Faganeli et al. 2003), a shallow semienclosed basin $\left(A=500 \mathrm{~km}^{2}\right)$ with a maximum water depth of $25 \mathrm{~m}$ (Fig. 1). High $\mathrm{Hg}$ concentrations both in sediments (0.10-23.30 $\mathrm{mg} \mathrm{kg}^{-1}$; Covelli et al. 2001) and in the suspended particulate matter ( $\mathrm{PHg}, 0.20-2.70 \mathrm{mg} \mathrm{kg}^{-1}$; Covelli et al. 


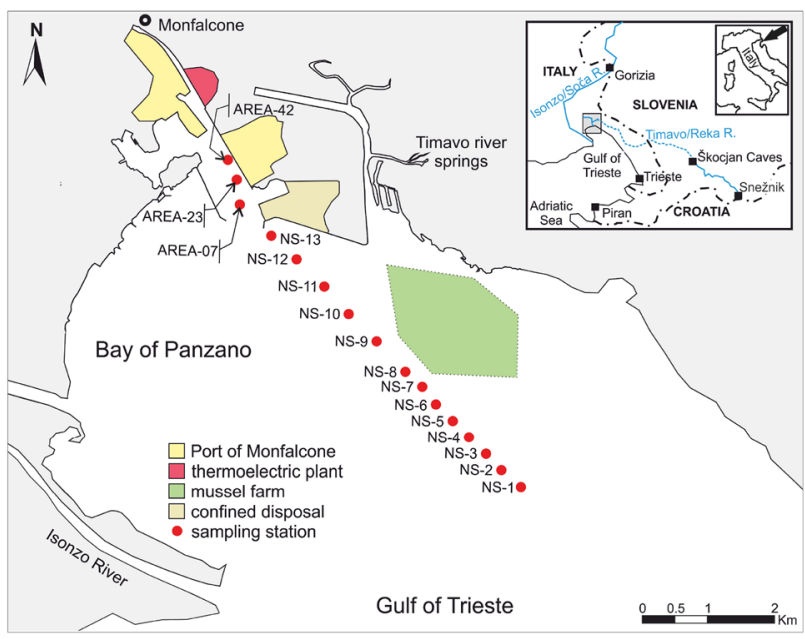

Fig. 1 Map of the study area and location of the sampling sites along the main axis of the channel approaching the Port of Monfalcone in the Gulf of Trieste

2007) were also found to be two orders of magnitude higher than the natural background $\left(0.13 \pm 0.04 \mathrm{mg} \mathrm{kg}^{-1}\right.$ (Covelli et al. 2006). Moreover, investigations on $\mathrm{Hg}$ mobility at the sediment-water interface were performed (Emili et al. 2014, 2016), in particular when hypoxic-anoxic conditions (Ullrich et al. 2001) promote inorganic $\mathrm{Hg}$ transformation into methylmercury $(\mathrm{MeHg})$, the most toxic organic chemical form easily bioaccumulated by biota. Several studies on $\mathrm{Hg}$ bioaccumulation in the aquatic trophic chain have also been done in this coastal environment, since aquaculture activities such as clam harvesting and mussel and fish farming are common (e.g. Giani et al. 2012; Petranich et al. 2018).

In the present study, 16 sediment samples were collected from the main channel approaching the Port of Monfalcone (Fig. 1), one of the northernmost ports of the Adriatic Sea in the Gulf of Trieste, to evaluate the potential release of $\mathrm{Hg}$ from sediment to the water column due to resuspension caused by dredging. The aim was to identify the $\mathrm{Hg}$ chemical forms present in the sediments by applying two different speciation approaches: (1) the thermo-desorption (TD) technique which is based on the real-time detection of $\mathrm{Hg}$ released from the sediment matrix during gradual heating (Mashyanov et al. 2017); (2) the Selective Sequential Extraction (SSE) procedure (Bloom et al. 2003), which applies five extracting solutions able to recover different $\mathrm{Hg}$ species from the most labile (e.g. $\mathrm{HgCl}_{2}$ ) to the most stable form $(\alpha-\mathrm{HgS})$.

\section{Materials and Methods}

The Bay of Panzano (Fig. 1), located in the north-eastern sector of the Gulf of Trieste, is a shallow and sheltered embayment prone to the accumulation of fine sediments.
The Port of Monfalcone, situated between the Isonzo River mouth to the south and a mussel farming area to the west, is connected to the open sea by a main access channel for which dredging is planned in the near future to allow for the navigation of cargo with a high draft.

Sediment cores were collected by a scuba diver by handpushing an inhouse modified Shelby corer $(96 \mathrm{~cm}$ i.d., $200 \mathrm{~mm}$ length) into the sediment from 16 sites (Fig. 1) along the main axis of the channel approaching the Port of Monfalcone. The sediment cores were extruded on board and the first $20 \mathrm{~cm}$ of the samples taken were homogenised, collected in glass containers and stored in a cool, dark room $\left(\sim 4^{\circ} \mathrm{C}\right)$ before total $\mathrm{Hg}(\mathrm{THg})$ concentration and speciation analyses and grain-size determination.

For grain-size analyses, approximately $20 \mathrm{~g}$ of fresh sediment were treated with $\mathrm{H}_{2} \mathrm{O}_{2}(10 \%)$ for a $24 \mathrm{~h}$ period to eliminate most of the organic matter. Subsequently, the sediment was wet-sieved through a $2 \mathrm{~mm}$ sieve to remove coarse shelly fragments. The resulting $<2 \mathrm{~mm}$ fraction was analysed using a laser granulometer (Malvern Mastersizer mod. 2000).

Total Hg in the dry sediment was determined using the Direct Mercury Analyser (DMA-80, Milestone) according to the EPA Method 7473. The limit of detection (lod), expressed as the amount of $\mathrm{Hg}$ content in a sample, was approximately $0.005 \mathrm{ng}$. Samples were analysed in triplicate and the results were compared with the values obtained on the basis of three replicates $\left(2.81 \pm 0.15 \mathrm{mg} \mathrm{kg}^{-1} \mathrm{Hg}\right)$ of a certified reference material $\left(2.98 \pm 0.36 \mathrm{mg} \mathrm{kg}^{-1}\right.$; PACS-3 Marine Sediment CRM, NRCC, Canada), and the relative standard deviation of at least three determinations was $<2 \%$.

Each $\mathrm{Hg}$ species in a solid matrix interacts in different ways, exhibiting a varying degree of solubility and mobility (Rumayor et al. 2013). The TD technique, the so-called thermoscanning technique, represents the powerful and rapid application for the direct analysis of $\mathrm{Hg}$ species in solid samples. This technique is based on the real-time detection of $\mathrm{Hg}$ release from a sample during gradual heating (Mashyanov et al. 2017), where each $\mathrm{Hg}$ species is released from the matrix according to its desorption temperature (Rumayor et al. 2013).

In this study, the RA-915 Mercury analyser coupled to a Pyro-915 + furnace (Lumex Instruments) were used to thermoscan all the samples. Approximately $70-80 \mathrm{mg}$ of sample was placed into the quartz boat of a thermocouple and inserted into the furnace where the temperature was gradually increased from ambient to $710^{\circ} \mathrm{C}\left(0.5^{\circ} \mathrm{C} \mathrm{s}^{-1}\right)$. The thermocouple was used to continuously monitor the temperature increase. Quantification was carried out by peak integration using the RAPID software. The set was calibrated with the SBPS-3 reference material $\left(310 \mu \mathrm{g} \mathrm{kg}^{-1}\right)$ and precision and accuracy were determined using a sediment standard reference material (PACS-3). To detect $\mathrm{Hg}$ species in the 
samples, standard $\mathrm{Hg}$ compounds such as cinnabar $(\alpha-\mathrm{HgS}$, from the Idrija mine), meta-cinnabar $(\beta-\mathrm{HgS})$ and mercury oxide ( $\mathrm{HgO}$ red), which was the result of extremely high concentrations of $\mathrm{Hg}$, were mixed with synthetic $\mathrm{CaCO}_{3}$ and then desorbed. The choice of the synthetic $\mathrm{CaCO}_{3}$ is due to the mineralogical characteristics of the sediments which are rich in carbonates (Brambati 1970).

The SSE procedure was performed on six sediment samples (NS-3, NS-4, NS-5, NS-6, NS-7 and NS-8) representative of the whole sample set. These samples were chosen as they were taken from a location close to the mussel farm which is considered the main recipient of the potential effects induced by the resuspension of $\mathrm{Hg}$ in the water column. In addition, according to the high total $\mathrm{Hg}$ concentration, these sediment samples also exceeded the contamination threshold limit for soils in sites intended for commercial and industrial use $\left(5 \mathrm{mg} \mathrm{kg}^{-1}\right)$ established by Italian Legislative Decree n. 152/06. This is of relevant concern since $5 \mathrm{mg} \mathrm{kg}^{-1}$ is the threshold limit in case the proposed purpose is to confine dredged sediments to a coastal disposal site (Fig. 1) planning their re-use without any physical or chemical treatment of remediation. One possible destination for these sediments, in fact, is their relocation to the harbour area to enlarge the dock area.

The five-step procedure described by Bloom et al. (2003), and subsequently adapted for sediments by Shi et al. (2005), consists of five reagent solutions with increasing extracting capacity (Fig. 3). After the last step, the solid residue was air-dried and analysed with DMA-80. The analysis of the five extracted solutions was performed by applying the Cold Vapour-Atomic Fluorescence Spectrometry (CV-AFS) technique. The method was verified for all samples by summing the ratio of the extracted $\mathrm{Hg}$ in each phase $\left(\mathrm{Hg}_{\mathrm{x}}\right)$ to $\mathrm{THg}$ in the sample $\left(\Sigma \mathrm{Hg}_{\mathrm{x}} / \mathrm{THg}\right)$.

\section{Results and Discussion}

According to Shepard's (1954) textural classification, surface sediments are dominated by silt $(67.8 \%-82.5 \%)$, followed by sand $(0.4 \%-15.7 \%)$ and clay $(11.6 \%-28.8 \%)$ (Table 1). The surface sediments displayed a variability of two orders of magnitude for $\mathrm{THg}$ concentrations: from $0.30 \mathrm{mg} \mathrm{kg}^{-1}$ (NS-12) to $13.5 \mathrm{mg} \mathrm{kg}^{-1}$ (NS-5), showing a decreasing trend from the offshore area to the innermost sector of the port (Table 1). High concentrations of trace elements in sediments are generally associated with the fine sediment fractions such as silt and clay (Acquavita et al. 2012a). This peculiarity is mainly due to physico-chemical factors that favour the element retention capacity of the finest particles, namely silt and clay (Bengston and Picado 2008): specific surface area, ion-exchange capacity, surface electric charges (as clay minerals), organic matter content
Table 1 Grain-size and $\mathrm{THg}$ concentrations in the sediment samples from the innermost sector of the channel to the offshore area

\begin{tabular}{llllc}
\hline Sample & $\begin{array}{l}\text { Sand }(\%) \\
(2000- \\
62.5 \mu \mathrm{m})\end{array}$ & $\begin{array}{l}\text { Silt }(\%) \\
(62.5-2 \mu \mathrm{m})\end{array}$ & $\begin{array}{l}\text { Clay }(\%) \\
(<2 \mu \mathrm{m})\end{array}$ & $\mathrm{THg}\left(\mathrm{mg} \mathrm{kg}^{-1}\right)$ \\
\hline AREA-42 & 15.7 & 72.7 & 11.6 & $0.54 \pm 0.04$ \\
AREA-23 & 10.4 & 75.3 & 14.3 & $0.36 \pm 0.04$ \\
AREA-07 & 0.6 & 76.2 & 23.2 & $2.81 \pm 0.25$ \\
NS-13 & 8.1 & 76.4 & 15.4 & $0.58 \pm 0.02$ \\
NS-12 & 7.0 & 71.6 & 21.4 & $0.30 \pm 0.00$ \\
NS-11 & 3.2 & 77.0 & 19.8 & $1.00 \pm 0.19$ \\
NS-10 & 1.9 & 73.7 & 24.4 & $0.94 \pm 0.12$ \\
NS-9 & 2.4 & 72.8 & 24.8 & $1.12 \pm 0.05$ \\
NS-8 & 7.8 & 82.5 & 9.7 & $6.36 \pm 0.05$ \\
NS-7 & 3.0 & 72.4 & 24.6 & $8.65 \pm 0.05$ \\
NS-6 & 3.4 & 67.8 & 28.8 & $8.34 \pm 0.27$ \\
NS-5 & 0.4 & 73.3 & 26.3 & $13.5 \pm 0.27$ \\
NS-4 & 0.5 & 71.6 & 27.9 & $11.1 \pm 0.19$ \\
NS-3 & 0.4 & 77.9 & 21.7 & $9.01 \pm 0.27$ \\
NS-2 & 0.6 & 72.3 & 27.1 & $7.32 \pm 0.31$ \\
NS-1 & 0.5 & 71.4 & 28.1 & $8.47 \pm 0.12$ \\
\hline
\end{tabular}

and the occurrence of $\mathrm{Fe}$ and $\mathrm{Mn}$ oxy-hydroxides (Feyte et al. 2010). However, previous studies in the Gulf of Trieste have demonstrated that this element is distributed in association with all the grain-size fractions $<2 \mathrm{~mm}$ (Covelli et al. 2001). By applying the TD technique, Biester et al. (2000) also indicated that $\mathrm{Hg}$ in this area is mostly present in detrital form (cinnabar) in sandy-silty sediments near the Isonzo River mouth, whereas, in the more distant areas, it is in ionic form $\left(\right.$ as $\mathrm{Hg}^{2+}$ ) bonded to fine particles adsorbed onto clay minerals and/or partially associated with organic matter.

The results obtained using the TD technique applied to all the sediment samples showed three ranges of temperature peaks for $\mathrm{Hg}$ release: $252-275^{\circ} \mathrm{C}, 300-364^{\circ} \mathrm{C}$ and $454-475^{\circ} \mathrm{C}$ (Fig. 2). By comparing the TD curves obtained from each sediment sample with those of single standard $\mathrm{Hg}$ compounds, the $\mathrm{Hg}$ species occurring in the samples may be identified. Three different temperature peaks corresponding to the maximum release of $\mathrm{Hg}$ from the standard compounds were observed: $351 \pm 12.7^{\circ} \mathrm{C}\left(\alpha-\mathrm{HgS}_{\text {Idrija }}\right)$, $226 \pm 8.0^{\circ} \mathrm{C}(\beta-\mathrm{HgS})$ and $559 \pm 12.6^{\circ} \mathrm{C}(\mathrm{HgO}$ red $)$.

The release of $\mathrm{Hg}$ species weakly associated with the sediment mineral matrix generally occurs at temperatures lower than $250^{\circ} \mathrm{C}$ (Biester et al. 2000; Cavoura et al. 2019 and references therein), whilst higher desorption temperatures are required to release $\mathrm{Hg}$ species strongly associated with organic compounds such as humic acids or present as $\alpha-\mathrm{HgS}$ (Biester et al. 2000).

The sediments sampled in the innermost sector of the port (Area-42, Area-23 and Area-07) showed TD curves characterised by two peaks: the first at $258^{\circ} \mathrm{C}$ and the second at 

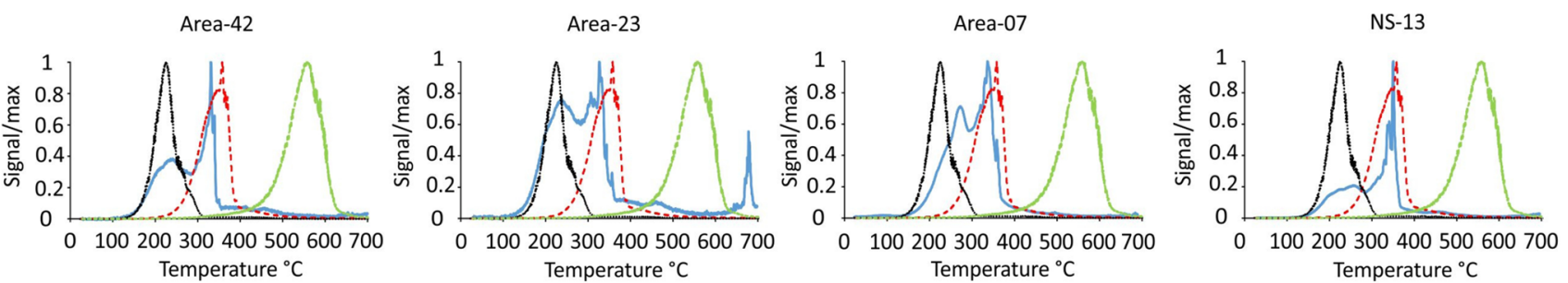

NS-12
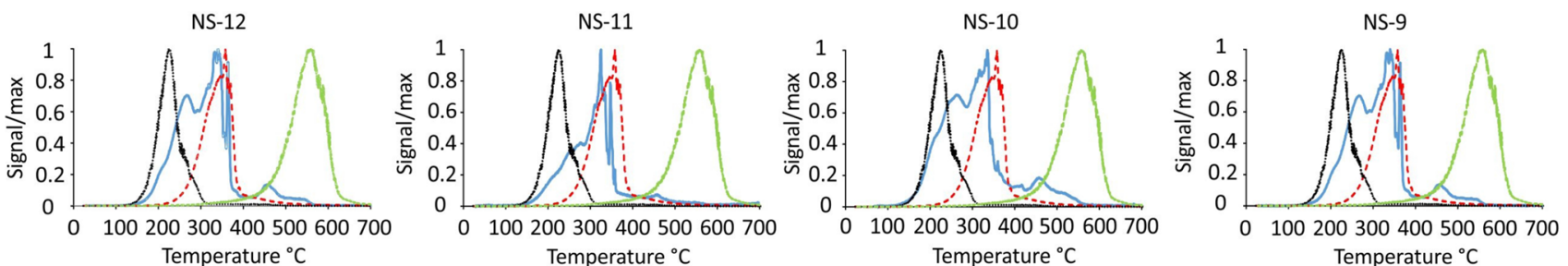

NS-8

NS-7
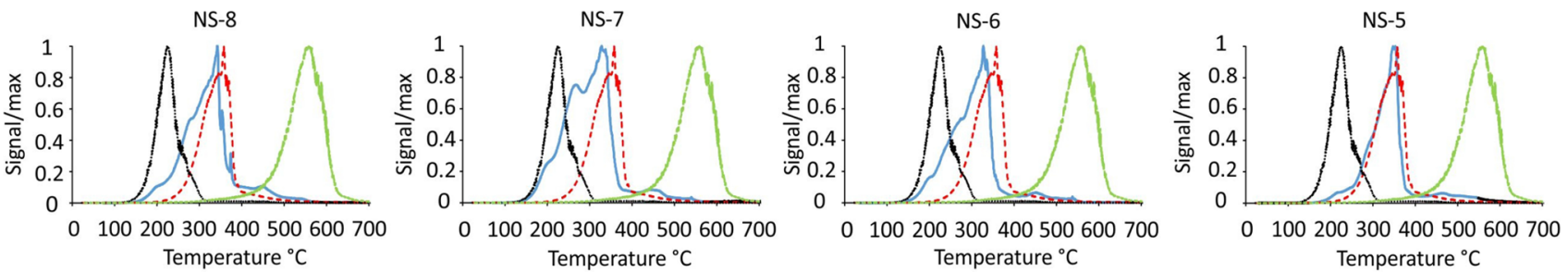

NS-4

NS-3
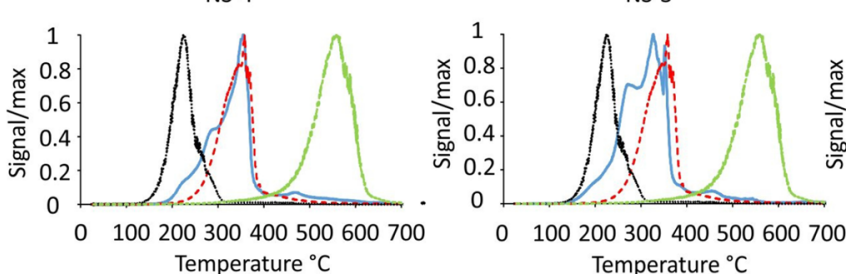

NS-2

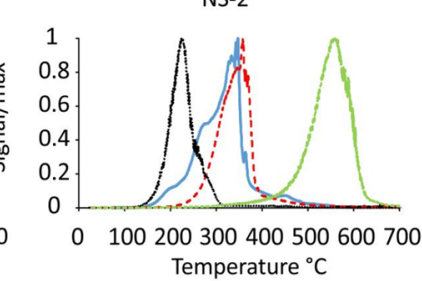

NS-1

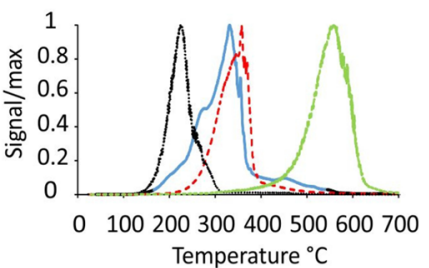

Legend: - Sample $---\alpha-\mathrm{HgS}$ Idrija $\cdots \cdot \cdots \cdot \mathrm{HgS}-\cdots \mathrm{HgO}$ red

Fig. 2 Thermoscanning (TD) curves obtained from sediment samples and standard Hg compounds

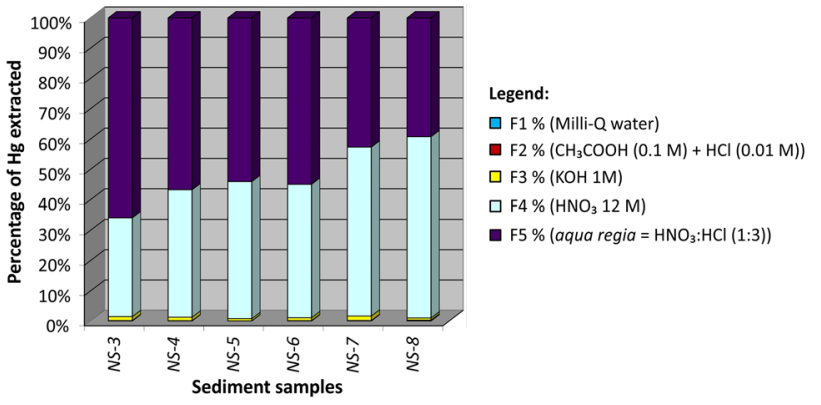

Fig. 3 Mercury fractions (\%) obtained by the SSE procedure performed on six samples

$331{ }^{\circ} \mathrm{C}$, which could correspond to the two cinnabar species, $\beta-\mathrm{HgS}$ and $\alpha-\mathrm{HgS}_{\text {Idrija, }}$, respectively (Fig. 2). This difference in terms of desorption temperature between the two cinnabar species is related to the lower stability of $\beta-\mathrm{HgS}$ compared to $\alpha-\mathrm{HgS}_{\text {Idrija }}$, for which less energy, and then lower temperature, is required to desorb $\mathrm{Hg}$.
Rumayor et al. (2013) and Baptista-Salazar et al. (2017) also found the temperature peak of $\alpha-\mathrm{HgS}$ in standard compounds at $305 \pm 12^{\circ} \mathrm{C}$ and approximately at $330^{\circ} \mathrm{C}$ in the samples. A similar explanation can also be valid for the other sediment samples, where $\alpha-\mathrm{HgS}$ and $\beta-\mathrm{HgS}$ correspond to the totality of the $\mathrm{Hg}$ present. Moreover, for some samples (NS-8, NS-9, NS-10 and NS-12), small Hg peaks between 400 and $500^{\circ} \mathrm{C}$ were detected $(<1.5 \%$ on $\mathrm{THg})$, and attributed to $\mathrm{HgO}$ red, as suggested by Biester et al. (2000) and Sedlar et al. (2015), despite the TD curve of the standard compound showing the maximum peak at $559^{\circ} \mathrm{C}$ (Fig. 2). This discrepancy could be due to the characteristics of the sedimentary matrix which may interfere with the release of $\mathrm{Hg}$, anticipating or delaying it with respect to the standard compound (Mashyanov et al. 2004).

The SSE procedure allowed for the differentiating of $\mathrm{Hg}$ compounds in terms of dissimilar behaviour classes (Bloom et al. 2003). The $\mathrm{F} 1$ and $\mathrm{F} 2$ fractions, which comprise highly soluble and easily exchangeable compounds (i.e. $\mathrm{HgCl}_{2}$, $\mathrm{HgSO}_{4}$ and $\mathrm{HgO}$ ) and are fully dissolved by the "in vitro 
human stomach simulation", showed very low percentages of $\mathrm{Hg}$ extracted (Fig. 3).

These two above-mentioned fractions are considered the main potential substrates for $\mathrm{Hg}$ methylation (Ullrich et al. 2001). However, the maximum value of the sum F1+F2 for our samples is $0.36 \%$ (avg. $0.21 \%$ ) which appears to limit the availability of inorganic $\mathrm{Hg}$ as substrate for methylation. If compared to $\mathrm{Hg}$ speciation studies performed on coastal sediments (Table 2), the maximum value obtained in the study area is higher than those found at the Isonzo river mouth $(0.11 \%$, Emili et al. 2014), the Grado Lagoon $(0.22 \%$, Covelli et al. 2011) and Guanabara Bay (0.11\%, Covelli et al. 2012), where $\mathrm{Hg}$ was directly discharged into the aqueous media from a chlor-alkali plant (CAP). Comparable percentages were found in the Ravenna Lagoon $(0.40 \%$, Covelli et al. 2011), impacted by $\mathrm{Hg}$ from an acetaldehyde production plant where $\mathrm{Hg}$ was used as a catalyst, and in the Taranto Harbour (0.30\%, Emili et al. 2016). Conversely, a notably higher percentage of F1 + F2 (11.65\%) was found in the Aussa River sediments which received effluents from a CAP (Covelli et al. 2009). The results obtained from our study area for the two most mobile fractions does not constitute an issue of particular concern with respect to other coastal sediments contaminated by $\mathrm{Hg}$.

The F3 fraction, corresponding to the organo-chelated $\mathrm{Hg}$ fraction, bound to the organic substance (humic, fulvic and amino acids) with a moderate mobility, is also extremely low in terms of percentage $(0.71 \%-1.47 \%$, avg $1.06 \%)$. Bloom et al. (2003) stated that inorganic Hg extracted in the F3 fraction is mainly correlated with methylation potential. By adding the F3 fraction to the sum F1 + F2, it can be hypothesised that the three fractions may constitute the $\mathrm{Hg}$ pool for methylation. Particulate-bound $\mathrm{Hg}$ (II) may not have to be desorbed or dissolved in the aqueous phase to make it available for microbial uptake and methylation (Zhang et al. 2019). Dissolved organic matter (DOM) binds strongly with both $\mathrm{Hg}$ and $\mathrm{MeHg}$ in natural ecosystems and affects bioavailability depending on DOM composition since terrestrial
DOM shows an inhibitory effect on $\mathrm{MeHg}$ uptake by bacteria and phytoplankton compared to marine DOM (Schartup et al. 2015). However, to assess the bioavailability of $\mathrm{MeHg}$ is complicated due to several processes that occur between the solid and liquid phases. $\mathrm{MeHg}$ is mainly produced in the surface sediments by anaerobic bacteria (Hsu-Kim et al. 2013). MeHg concentrations in aquatic systems vary widely and do not necessarily correlate with the total amount of mercury in water or sediments (Acquavita et al. 2012a; Covelli et al. 2001). In addition, it is the balance between methylation and demethylation, due to sunlight at the surface of the water column or in the sediments, which determines the amount of $\mathrm{MeHg}$ in an aquatic system (Hines et al. 2006). The highest percentage of $\mathrm{F} 1+\mathrm{F} 2+\mathrm{F} 3$ obtained for our samples $(1.69 \%)$ compared to other $\mathrm{Hg}$ contaminated sediments (Table 2) is only higher than the Isonzo River mouth $(0.88 \%)$ and than 3 out of 6 samples from Guanabara Bay. For the other sites (Table 2), the sum F1 +F2 +F3 is always higher compared to this work, especially for the Aussa River sediments. Overall, in spite of the total $\mathrm{Hg}$ concentrations in sediments, the three fractions with high mobility are found only in trace amounts.

Indeed, most of the extracted $\mathrm{Hg}$ (approximately 99\%) was included in the last two fractions, distributed in a variable percentage between F4 and F5, depending on the sample (Fig. 3). With the exception of NS-7 and NS-8, the F5 fraction, which is characterised by a mineral bound fraction and includes $\alpha-\mathrm{HgS}, \beta-\mathrm{HgS}$ and $\mathrm{Hg}$ immobilised by pyrite (Huerta-Diaz and Morse 1992), prevails (>50\%). The F4 fraction represents, on average, $46 \%$ of the extracted $\mathrm{Hg}$ and constitutes the most abundant fraction in NS-7 (55.6\%) and NS-8 (59.7\%). This fraction includes the forms of $\mathrm{Hg}$ bound to strong complexes, mainly elemental $\mathrm{Hg}$ together with the $\mathrm{Hg}$ forms linked to amorphous organo-sulphides and to the crystalline phase with Fe and Mn oxides. These compounds are normally poorly soluble and not very bio-accessible, which can release significant amounts of $\mathrm{Hg}$ only in exceptional conditions of anoxia (Emili et al. 2014). Moreover,

Table 2 Partitioning of $\mathrm{Hg}$ in the solid phase according to the selective extraction procedure in selected costal sites

\begin{tabular}{llllllcc}
\hline & $\mathrm{n}$ & $\mathrm{Hg}\left(\mathrm{mg} \mathrm{kg}^{-1}\right)$ & $\mathrm{Hg}-\mathrm{w}(\%)$ & $\mathrm{Hg}-\mathrm{h}(\%)$ & $\mathrm{Hg}-\mathrm{o}(\%)$ & $\mathrm{Hg}-\mathrm{e}(\%)$ & $\mathrm{Hg}-\mathrm{s}(\%)$ \\
\hline (1) This study & 5 & $6.36-13.50$ & $0.08-0.18$ & $0.04-0.18$ & $0.71-1.47$ & $32.6-59.7$ & $39.3-56.7$ \\
(2) Isonzo R. mouth (ITA) & 1 & 13.27 & 0.08 & 0.03 & 0.77 & 23.45 & 75.68 \\
(3) Grado Lagoon (ITA) & 2 & $10.75-13.37$ & $0.16-0.20$ & $0.01-0.02$ & $2.72-4.28$ & $43.58-53.31$ & $42.24-53.49$ \\
(4) Aussa River (ITA) & 6 & $0.82-5.69$ & $0.66-5.60$ & $0.96-6.05$ & $5.59-24.81$ & $33.11-90.57$ & $0-57.95$ \\
(5) Ravenna Lagoon (ITA) & 2 & $14.40-19.10$ & $0.20-0.38$ & $0-0.02$ & $4.77-6.32$ & $87.00-87.81$ & $5.67-7.83$ \\
(6) Taranto Harbour (ITA) & 1 & 6.61 & 0.30 & 0.00 & 4.20 & 93.10 & 2.30 \\
(7) Guanabara Bay (BRA) & 6 & $1.54-3.22$ & $0-0.02$ & $0-0.09$ & $1.11-6.69$ & $92.85-98.65$ & $0.15-1.46$ \\
\hline
\end{tabular}

Contamination is due to mining activities (1, 2 and 3), chlor-alkali plant (4,7), acetaldehyde factory (5) and Italian Navy shipyard-arsenal (6). From: (2) Emili et al. (2014); (3,5) Covelli et al. (2011); (4) Covelli et al. (2009); (6) Emili et al. (2016); (7) Covelli et al. (2012) 
since elemental $\mathrm{Hg}$ was not detected in the TD analysis (maximum peak at $100^{\circ} \mathrm{C}$ ), the $\mathrm{F} 4$ of the SSE should correspond to $\mathrm{Hg}$ forms linked to amorphous organo-sulphides and to the crystalline phase with $\mathrm{Fe}$ and Mn oxides. In agreement with Reis et al. (2015), indeed, our first peak at $258^{\circ} \mathrm{C}$ could also correspond to $\mathrm{Hg}$ bound to iron oxides which is released between 100 and $285^{\circ} \mathrm{C}$ rather than $\beta-\mathrm{HgS}$. However, no standard for $\mathrm{Hg}$ associated with $\mathrm{Fe}$ oxides was available to verify this hypothesis.

In conclusion, $\mathrm{Hg}$ distribution in the different fractions obtained by SSE (Fig. 3) indicates that the element is strongly associated with the less mobile fractions. The TD technique performed on all the sediment samples confirmed that the main $\mathrm{Hg}$ forms in these sediments are not easily remobilisable. According to these results, we should not expect a large contribution of $\mathrm{Hg}$ released in its dissolved form due to the physical resuspension of bottom sediments. In other contexts, it was observed that metal release during sediment disturbance events tends to be higher under oxic conditions thus suggesting oxidative dissolution of sulphide mineral phases and oxidative degradation of organochelated $\mathrm{Hg}$ compounds which may contribute to high $\mathrm{Hg}$ concentrations (Gibson et al. 2015). Conversely, our results are in agreement with experimental observations obtained from simulating a resuspension event of bottom sediments (11.4 $\mathrm{mg} \mathrm{kg}^{-1}$ total $\mathrm{Hg}$ and $7.5 \mathrm{ng} \mathrm{g}^{-1} \mathrm{MeHg}$ ) periodically subjected to dredging activities in the Grado Lagoon (Acquavita et al. 2012b). The experiment revealed that the release of $\mathrm{Hg}$ species from the solid to the dissolved phase became negligible quickly after the event. The concentrations of both inorganic $\mathrm{Hg}$ and $\mathrm{MeHg}$ found in the water column after resuspension were comparable to those monitored in situ in the Lagoon. This evidence supports the hypothesis that the effects of a resuspension event are temporary due to dilution of the $\mathrm{Hg}$ species in the water column and their settling back to the bottom in association with the sediment particles.

Results from this research demonstrated that both speciation techniques were found to be valid and comparable to each other to discriminate between mobile and non-mobile $\mathrm{Hg}$ chemical species from the sediment to the water column.

Acknowledgements A special thanks to Stefano Caressa and Emiliano Gordini for sampling operations. The authors are grateful to an anonymous reviewer and to the Editor of BCET for the useful suggestions provided. Karry Close is warmly acknowledged for proofreading the manuscript.

Funding Open access funding provided by Università degli Studi di Trieste within the CRUI-CARE Agreement..

Open Access This article is licensed under a Creative Commons Attribution 4.0 International License, which permits use, sharing, adaptation, distribution and reproduction in any medium or format, as long as you give appropriate credit to the original author(s) and the source, provide a link to the Creative Commons licence, and indicate if changes were made. The images or other third party material in this article are included in the article's Creative Commons licence, unless indicated otherwise in a credit line to the material. If material is not included in the article's Creative Commons licence and your intended use is not permitted by statutory regulation or exceeds the permitted use, you will need to obtain permission directly from the copyright holder. To view a copy of this licence, visit http://creativecommons.org/licenses/by/4.0/.

\section{References}

Acquavita A, Covelli S, Emili A, Berto D, Faganeli J, Giani M, Horvat M, Koron N, Rampazzo F (2012a) Mercury in the sediments of the Marano and Grado Lagoon (northern Adriatic Sea): sources, distribution and speciation. Estuar Coast Shelf Sci 113:20-31

Acquavita A, Emili A, Covelli S, Faganeli J, Predonzani S, Koron N, Carrasco L (2012b) The effects of resuspension on the fate of $\mathrm{Hg}$ in contaminated sediments (Marano and Grado Lagoon, Italy): short-term simulation experiments. Estuar Coast Shelf Sci 113:32-40

Baptista-Salazar C, Richard J-H, Horf M, Rejc M, Gosar M, Biester $\mathrm{H}$ (2017) Grain-size dependence of mercury speciation in river suspended matter, sediments and soils in a mercury mining area at varying hydrological conditions. Appl Geochem 81:132-142

Bengston G, Picado F (2008) Mercury sorption to sediments: dependence on grain size, dissolved organic carbon, and suspended bacteria. Chemosphere 73:526-531

Biester H, Gosar M, Covelli S (2000) Mercury speciation in sediments affected by dumped mining residues in the drainage area of the idrija mercury mine, slovenia. Environ Sci Technol 34:3330-3336

Bloom NS, Preus E, Katon J, Hiltner M (2003) Selective extractions to assess the biogeochemically relevant fractionation of inorganic mercury in sediments and soils. Anal Chim Acta 479:233-248

Bocchetti R, Fattorini D, Pisanelli B, Macchia S, Oliviero L, Pilato F, Pellegrini D, Regoli F (2008) Contaminant accumulation and biomarker responses in caged mussels mytilus galloprovincialis to evaluate bioavailability and toxicological effects of remobilized chemicals during dredging and disposal operations in harbour areas. Aquatic Toxicol 89:257-266

Brambati A (1970) Provenienza, trasporto e accumulo dei sedimenti recenti nelle lagune di marano e di grado e nei litorali tra i fiumi Isonzo e tagliamento. Mem della Soc Geolo Ital 9(4):281-329

Caplat C, Texier H, Barillier D, Lelievre C (2015) Heavy metals mobility in harbour contaminated sediments: the case of Port-en-Bessin. Mar Pollut Bull 50:504-511

Cavoura O, Davidson CM, Keenan HE, Reis AT, Pereir E (2019) Assessing mercury mobility in sediment of the Union Canal, Scotland, UK by sequential extraction and thermal desorption. Arch Environ Con Tox 76:650-656

Covelli S, Faganeli J, Horvat M, Brambati M (2001) Mercury contamination of coastal sediments as the result of long-term cinnabar mining activity (Gulf of Trieste, northern Adriatic sea). Appl Geochem 16:541-558

Covelli S, Fontolan G, Faganeli J, Ogrinc N (2006) Antrophogenic markers in the Holocene stratigraphic sequence of the Gulf of Trieste (northern Adriatic Sea). Mar Geol 230:29-51

Covelli S, Piani R, Acquavita A, Predonzani S, Faganeli J (2007) Transport and dispersion of particulate $\mathrm{Hg}$ associated with a river plume in coastal N2007orthern Adriatic environments. Mar Pollut Bull 55:436-450

Covelli S, Acquavita A, Piani R, Predonzani S, De Vittor C (2009) Recent and past contamination of mercury in an estuarine 
environment (Marano lagoon, Northern Adriatic, Italy). Estuar Coast Shelf Sci 82:273-284

Covelli S, Emili A, Acquavita A, Koron N, Faganeli J (2011) Benthic biogeochemical cycling of mercury in two contaminated northern Adriatic coastal lagoons. Cont Shelf Res 31:1777-1789

Covelli S, Protopsalti I, Acquavita A, Sperle M, Bonardi M, Emili A (2012) Spatial variation, speciation and sedimentary records of mercury in the Guanabara Bay (Rio de Janeiro, Brazil). Cont Shelf Res 39:29-42

Emili A, Carrasco L, Acquavita A, Covelli S (2014) A laboratory-incubated redox oscillation experiment to investigate $\mathrm{Hg}$ fluxes from highly contaminated coastal marine sediments (Gulf of Trieste, Northern Adriatic Sea). Environ Sci Pollut Res 21:4124-4133

Emili A, Acquavita A, Covelli S, Spada L, Di Leo A, Giandomenico S, Cardellicchio N (2016) Mobility of heavy metals from polluted sediments of a semi-enclosed basin: in situ benthic chamber experiments in Taranto's Mar Piccolo (Ionian Sea, Southern Italy). Environ Sci Pollut Res 23:12582-12595

Faganeli J, Horvat M, Covelli S, Fajon V, Logar M, Lipej L, Cermelj B (2003) Mercury and methylmercury in the Gulf of Trieste (northern Adriatic Sea). Sci Tot Environ 304:315-326

Feyte S, Tessier A, Gobeil C, Cossa D (2010) In situ adsorption of mercury, methylmercury and other elements by iron oxyhydroxides and organic matter in lake sediments. Appl Geochem 25:984-995

Fisher R, Stark C, Ridd P, Jones R (2015) Spatial patterns in water quality changes during dredging in tropical environments. PLoS ONE 10(12):e0143309. https://doi.org/10.1371/journal.pone.0143309

García-Ordiales E, Covelli S, Braidotti G, Petranich E, Pavoni E, SanzPrada L, Roqueñí N, Loredo J (2020) Mercury and arsenic mobility in resuspended contaminated estuarine sediments (Asturias, Spain): a laboratory-based study. Sci Tot Environ 744:140870

Giani M, Rampazzo F, Berto D, Maggi C, Mao A, Horvat M, Emili A, Covelli S (2012) Bioaccumulation of mercury in reared and wild Ruditapes philippinarum of a Mediterranean lagoon. Estuar Coast Shelf Sci 113:116-125

Gibson BD, Ptacek CJ, Blowes DW, Daugherty SD (2015) Sediment resuspension under variable geochemical conditions and implications for contaminant release. J Soils Sediments 15:1644-1656

Hines ME, Faganeli J, Adatto I, Horvat M (2006) Microbial mercury transformations in marine, estuarine and freshwater sediment downstream of the Idrija mercury mine, Slovenia. Appl Geochem 21:1924-1939

Hsu-Kim H, Kucharzyk KH, Zhang T, Deshusses MA (2013) Mechanisms regulating mercury bioavailability for methylating microorganisms in the aquatic environment: a critical review. Environ Sci Technol 47:2441-2456

Huerta-Diaz MA, Morse JW (1992) Pyritization of trace metals in anoxic marine sediments. Geochim Cosmochim Acta 56:2681-2702

Kelderman P, Osman A (2007) Effect of redox potential on heavy metal binding forms in polluted canal sediments in Delft (The Netherlands). Water Res 41:4251-4261

Mashyanov NR, Matsuyama A, Akagi H, Pogarev S, Ryzhov V (2004) Mercury thermos-speciation in contaminated soils and sediments. RMZ - Mater Geoenviron III 51:1980-1983
Mashyanov NR, Pogarev SE, Panova EG, Panichev N, Ryzhov V (2017) Determination of mercury thermospecies in coal. Fuel 203:973-980

Moog O, Stubauer I, Haimann M, Habersack H, Leitner P (2018) Effects of harbour excavating and dredged sediment disposal on the benthic invertebrate fauna of River Danube (Austria). Hydrobiologia 814:109-120

Petranich E, Covelli S, Acquavita A, Faganeli J, Horvat M, Contin M (2018) Evaluation of mercury biogeochemical cycling at the sediment-water interface in anthropogenically modified lagoon environments. J Environ Sci 68:5-23

Reis AT, Coelho JP, Rucandio I, Davidson CM, Duarte AC, Pereira E (2015) Thermo-desorption: a valid tool for mercury speciation in soils and sediments? Geoderma 237-238:98-104

Rumayor M, Diaz-Somoano M, Lopez-Anton MA, Martinez-Tarazona MR (2013) Mercury compounds characterization by thermal desorption. Talanta 114:318-322

Schartup AT, Ndu U, Balcom PH, Mason RP, Sunderland EM (2015) Contrasting effects of marine and terrestrially derived dissolved organic matter on mercury speciation and bioavailability in seawater. Environ Sci Technol 49:5965-5972

Schintu M, Marrucci A, Marras B, Galgani F, Buosi C, Ibba A, Cherchi A (2016) Heavy metal accumulation in surface sediments at the port of Cagliari (Sardinia, western Mediterranean): environmental assessment using sequential extractions and benthic foraminifera. Mar Pollut Bull 111:45-56

Schneider L, Maher WA, Potts J, Taylor AM, Batley GE, Krikowa F, Adamack A, Chariton AA, Gruber B (2018) Trophic transfer of metals in a seagrass food web: bioaccumulation of essential and non-essential metals. Mar Pollut Bull 131:468-480

Sedlar M, Pavlin M, Popovič A, Horvat M (2015) Temperature stability of mercury compounds in solid substrates. Open Chem 13:404-419

Shepard FP (1954) Nomenclature based on sand-silt-clay ratios. J Sediment Petrol 24:151-158

Shi J, Liang L, Jiang G, Jin X (2005) The speciation and bioavailability of mercury in sediments of Haihe River, China. Environ Int 31:357-365

Ullrich SM, Tanton TW, Abdrashitova SA (2001) Mercury in the aquatic environment: a review of factors affecting methylation. Crit Rev Environ Sci Technol 31:241-293

Zhang L, Wu S, Zhao L, Lu X, Pierce EM, Gu B (2019) Mercury sorption and desorption on organo-mineral particulates as a source for microbial methylation. Environ Sci Technol 53:2426-2433

Publisher's Note Springer Nature remains neutral with regard to jurisdictional claims in published maps and institutional affiliations. 